\title{
Trade Reforms and Integration of Cocoa Farmers into World Markets: Evidence from African and non-African Countries
}

\author{
Komi Tsowou ${ }^{1, *}$, Samuel K. Gayi² \\ ${ }^{1}$ Regional Integration and Trade Division, United Nations Economic Commission for Africa (UNECA), Addis Ababa, Ethiopia \\ ${ }^{2}$ Formally, Special Unit on Commodities, United Nations Conference on Trade and Development (UNCTAD), Geneva, Switzerland
}

\section{ARTICLE INFO}

\section{Article History}

Received 25 May 2019

Accepted 03 September 2019

Keywords

Cocoa markets

farmers

price transmission

error correction model

\begin{abstract}
The paper analyses cocoa farmers' integration into global markets taking into account trade reforms in five cocoa producing countries. The analysis investigates price transmission mechanisms from world to domestic cocoa markets in the context of trade liberalizing policy reforms. The empirical analysis of this study is carried out within the framework of the Error Correction Model. The results, while being mixed, suggest that the reforms have increased the exposure of farmers to world cocoa markets. However, this development is not associated with significant increases in the share of the world price accruing to farmers in cocoa major producing countries. For a sustainable cocoa economy, policies that create an enabling environment for farmers are critical.
\end{abstract}

(c) 2019 African Export-Import Bank. Publishing services by Atlantis Press International B.V. This is an open access article distributed under the CC BY-NC 4.0 license (http://creativecommons.org/licenses/by-nc/4.0/)

\section{INTRODUCTION}

Globally, there are about 5-6 million cocoa farmers and between 40 and 50 million people depend on cocoa for their livelihoods (WCF, 2012). The sector generates export revenues for governments; and employment and income for households in exporting countries. In Côte d'Ivoire and Ghana, for example, cocoa accounted for more than 30\% of export earnings over the period 1995-2014. ${ }^{1}$ Thus, the cocoa sector is important for reducing poverty and achieving sustainable development in producing countries. In consuming countries, cocoa plays an important role in confectionery, food and beverage industries. In addition, cocoa or cocoa wastes could be processed to obtain several by-products including animal feed, potash and soft drinks (ICCO, 2006).

These significant socioeconomic benefits of cocoa notwithstanding, the farmers, the backbone of the cocoa supply chain, have not profited much from it. A lion's share of the revenues generated along the cocoa global value chain (GVC) accrues to other stakeholders including manufacturers and retailers, while farmers only receive a very low share which does not permit them to enjoy a decent livelihood. For example, Cocoa Barometer (2015) estimates that cocoa farmers receive less than 7\% of the total value added to 1 ton of cocoa beans that are sold. Estimates of the International Labour Rights Forum (ILRF) also suggest that the net earnings of typical cocoa farmers with 2 ha of land in the top two cocoa producing countries, Côte d'Ivoire and Ghana, at about US $\$ 2.07$ and US $\$ 2.69$ per day, respectively, are just above the global poverty line of US\$1.90 per person per day (Lambert, 2014, p. 4). ${ }^{2}$ This unfortunate situation of cocoa farmers could imply that the impacts of trade liberalization policy reforms undertaken by cocoa producing countries in the 1980s and 1990s, in an effort to boost the incomes of cocoa growers (Gilbert, 2009; Wilcox and Abbott, 2006), have been subdued to date. The reforms were expected to increase cocoa producer prices by improving competition in, and therefore the efficiency of, cocoa markets at the domestic and international levels. They were also intended to reduce distortions in national trade policies such as excessive levels of domestic taxation and other inefficient government intervention mechanisms that had contributed to insulate domestic cocoa markets of producing countries from world price signals during the pre-reform period. ${ }^{3}$

After two or three decades of the implementation of trade liberalization policies in cocoa producing countries, examining how they have affected cocoa farmers' integration into the world markets is relevant to identify a way forward. This is the overarching goal of the paper which analyses price transmission mechanisms from world to domestic cocoa markets in the context of trade policy reforms. Domestic

"Corresponding author. Email: tsowou@un.org

Peer review under responsibility of the African Export-Import Bank

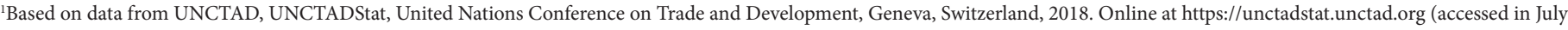
2018).

${ }^{2}$ Considering that the average size of rural households in these countries may exceed five people, the daily net income per person in these cocoa producing communities would be much lower than the global poverty line.

${ }^{3}$ It worth noting however that insulation of domestic markets from world markets can also result from other factors such as high transaction costs associated with poor infrastructure, transport and communication services (Badiane and Shively, 1998), non-competitive domestic marketing channels driven partly by oligopsonic structure and collusion among buyers as well as the number of marketing stages from producers to exporters (Rapsomanikis et al., 2006; Sharma, 2003). 
cocoa markets for five large producing countries in the world, namely, Cameroon, Côte d'Ivoire, Ecuador, Ghana and Indonesia, are examined. The choice of the countries is guided by availability of quality data, the importance of the country in cocoa production at the regional and global levels and the significance of the cocoa sector in their economies. Côte d'Ivoire and Ghana are the top two cocoa producers in the world, and together with Cameroon are the three biggest producers in Africa; Ecuador and Indonesia are among the largest cocoa producers in Latin America and Asia, respectively. The structure of cocoa markets in the selected countries exhibits different patterns (as discussed in the following section) which highlights some important lessons for cocoa producing countries across the world. Moreover, these selected countries have all implemented the reforms sufficiently long ago that the expected results, if any, should be observable at present. The empirical analysis of this study is carried out within the framework of the Error Correction Model (ECM) which has proved to be a useful tool for price transmission analysis in agricultural markets (Baffes and Gardner, 2003; Rapsomanikis et al., 2006; Worako et al., 2008).

More specifically, within a framework of the ECM, the paper first examines the degree to which world price signals have been transmitted to domestic cocoa markets of the selected countries taking into consideration trade policy reforms. It assesses how world and domestic cocoa markets of these countries are integrated in the short and long runs by capturing specific characteristics such as completeness, speed and asymmetry of the price transmission. Second, it discusses how any changes in the price transmission attributable to trade reforms have potentially affected shares of the world price accruing to cocoa farmers. Finally, based on the main findings of the empirical section, the paper identifies some key policy options that could contribute to providing a conductive environment to improve the efficiency of domestic cocoa markets of producing countries, while ensuring better prices for farmers. The contention is that if properly implemented, these policy recommendations should contribute to attaining a sustainable global cocoa economy and achieving some of the United Nations Sustainable Development Goals (SDGs) in cocoa farming communities, in particular eradicating poverty and hunger (SDGs 1 and 2) and providing decent work and livelihoods for cocoa growers (SDGs 3 and 8).

The paper contributes to the literature on farmers' integration into world markets and thus, into the GVCs for agricultural products. This study differs from previous works on a similar topic by expanding its data over a longer period postliberalization and, thus, improves the empirical framework. In addition, by covering five cocoa producing countries, the study provides some good insights for comparative analysis of domestic trade policies which would be useful for governments, development practitioners, the private sector and other stakeholders with an interest in the development of a sustainable cocoa economy.

The remainder of this paper is structured as follows. The next section provides a brief overview of the context of the cocoa sector and related trade liberalization reforms in the countries under consideration. The 'The Modelling Framework and Variable Description' section presents the modelling framework with data description. The 'Modelling Results and Discussions' section presents and discusses the main results of the empirical modelling. The last section concludes and discusses some policy implications emanating from the empirical study.

\section{THE COCOA MARKETS AND TRADE LIBERALIZATION}

This section provides a brief overview on how trade reforms have affected market structure in the cocoa producing countries of interest in this paper. It thereafter elucidates the theoretical underpinning of the research work, that is, the linkage between domestic and world markets of cocoa.

\subsection{Structure of Cocoa Markets and Trade Reforms}

The domestic markets of most cocoa producing countries have been historically characterized by government interventions through national trade policies and direct control of the marketing channels. These interventions were materialized, for example, in the forms of prohibitively high levels of export tariffs and quotas, and contributed to isolating national markets from price signals in world markets (Rapsomanikis et al., 2006; Sharma, 2003). However, in the wake of trade liberalization reforms, governments retreated progressively (Table 1). For example, prior to 1995, the domestic cocoa market in Côte d'Ivoire was managed by a government-controlled cocoa marketing board. Thereafter, the sector was liberalized with private buyers sourcing cocoa beans directly from farmers from the 1995-1996 crop season. In Cameroon, liberalization of domestic cocoa markets started from the 1989-1990 crop season. In the case of Ghana, although the country's marketing board is still responsible for cocoa beans export, the internal marketing of cocoa was liberalized during $1992-1993$ with private buyers starting to source beans from farmers (UNCTAD, 2008). In Ecuador, market-oriented reforms started in 1992 (Vos, 2000), whereas the corresponding year for Indonesia is 1985 (Baffes and Gardner, 2003). However, in the latter two countries, cocoa markets have been historically characterized by limited government intervention (Panlibuton and Lusby, 2006; Ton et al., 2008).

The reforms were expected to result in improved transmission of price signals from international to domestic cocoa markets, thereby contributing to a better integration of cocoa farmers into global markets (Rapsomanikis et al., 2006; Shepherd, 2004). This improved relationship may be evidenced in Figure 1 which shows the evolution of the world price of cocoa and cocoa producer prices in the five countries considered in this paper. The trends in producer prices compared with world price of cocoa tend to demonstrate a similar pattern. More interestingly, producer prices for all the five countries seem to track more closely the world price of cocoa from mid-1990s compared with the 1970s and the 1980s. These improvements in price relationships may have been partly due to trade liberalization reforms in the various producing countries-it is the objective of this paper to empirically test whether this is true.

The outcomes of trade reforms depend on the effectiveness of their implementation, strong policy and institutional environment, which are key enablers. 
Table 1 Key arguments for trade liberalization dates in the selected countries

\begin{tabular}{lcc}
\hline Country & $\begin{array}{c}\text { Key trade } \\
\text { liberalization date }\end{array}$ & Key argumentation \\
\hline $\begin{array}{l}\text { Cameroon } \\
\text { Côte d'Ivoire }\end{array}$ & 1990 & $\begin{array}{l}\text { Liberalization of domestic marketing and export trade started from the 1989/1990 crop season (UNCTAD, 2008). } \\
\text { From 1995/1996, exporters began to purchase cocoa directly from farmers. However, we may note that } \\
\text { disengagement of the state from the sector was progressive in the country (UNCTAD, 2008). } \\
\text { Market-oriented reforms with liberalization of trade and capital flow started around 1992 (Vos, 2000). However, the } \\
\text { cocoa sector in the country has historically been characterized by low government intervention (Ton et al., 2008). } \\
\text { The internal marketing of cocoa was liberalized during the 1992/93 cocoa season with private companies starting to } \\
\text { compete with Produce Buying Company, the purchasing arm of Ghana Cocobod (UNCTAD, 2008). The country's } \\
\text { cocoa board (Ghana Cocobod) is, however, still responsible for marketing cocoa beans in export markets. } \\
\text { Gradual relaxation of trade barriers started in 1985 (Baffes and Gardner, 2003). This notwithstanding, producer } \\
\text { prices in the country have been supported by an unregulated national cocoa market with limited government } \\
\text { policy intervention (Panlibuton and Lusby, 2006), at least before 2010 when a sliding tariff of up to 15\% was } \\
\text { introduced on exports of unprocessed beans (Neilson et al., 2013). }\end{array}$ \\
Indonesia & 1992 &
\end{tabular}

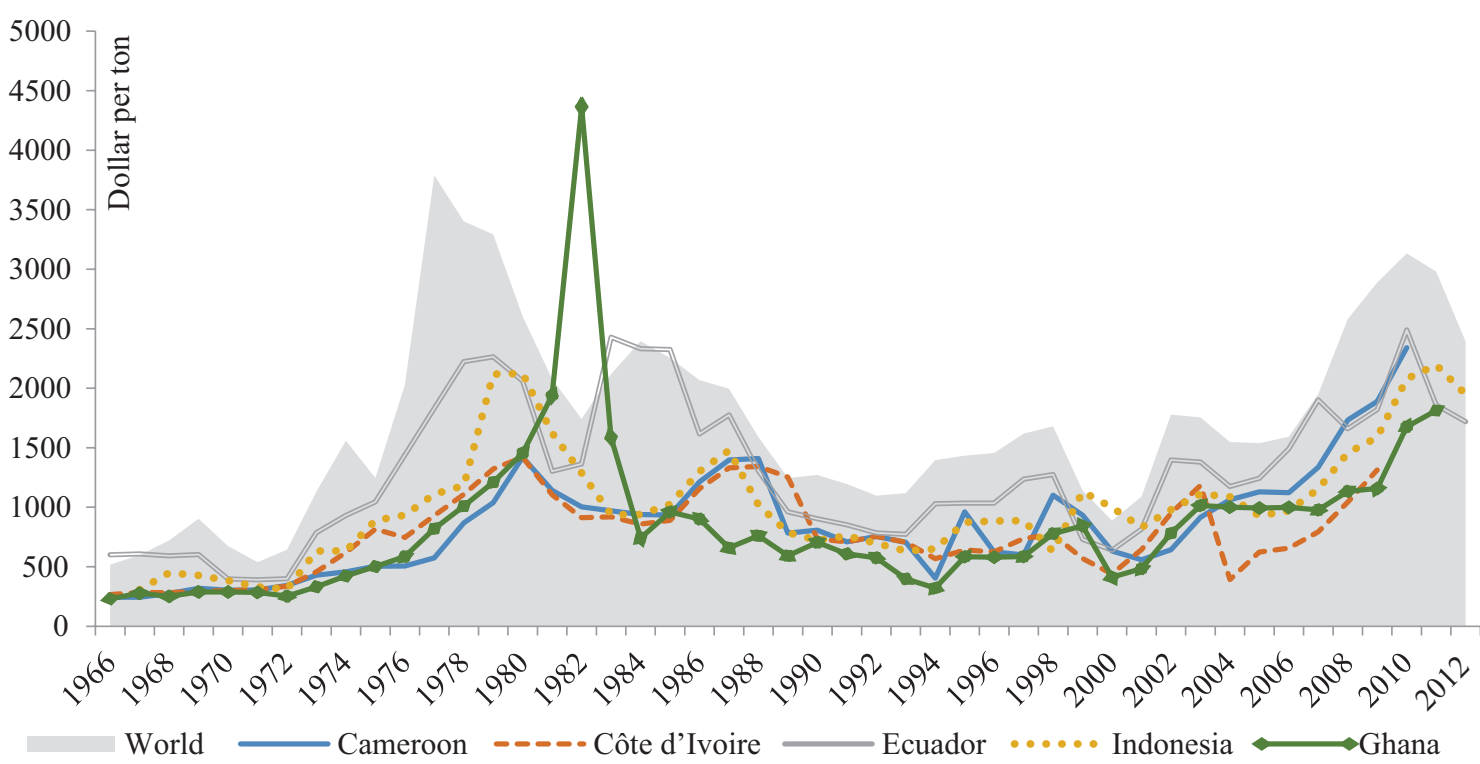

Figure 1 Producer prices in selected cocoa producing countries in relation to world price of cocoa. Source: Authors', based on data from UNCTADStat, World Bank-WDI, FAOStat and ICCO. Note: The time period covered by price series depends on data availability (see Section 3, The Modelling Framework and Variable Description). It is important to note the "abnormal" value of the cocoa producer price in Ghana in 1982, which exceeded the world price significantly. This was primarily due to a highly overvalued exchange rate, combined with an increase in producer prices in Ghana in the early 1980s (Kolavalli and Vigneri, 2011). In this study, the effect of this abnormal value is captured by a dummy variable.

The trade reforms have also unexpectedly resulted in a high degree of concentration in cocoa markets. At the upstream segment of the cocoa GVC, the main driving force is complexity of cocoa markets characterized by Transnational Corporations (TNCs)' ease of access to resources, such as finance, risk management instruments, as well as technologies, along with their objective of achieving scale economies. These characteristics have led most small players to leave cocoa marketing channels or merge with multinationals who took control over their activities (ACET, 2014; Gilbert, 2009). The resulting market structure could contribute to improving cost efficiency of the cocoa GVC, with potential benefits passed onto smallholders, including small farmers. However, high concentration, especially in the domestic cocoa markets, may have offset the benefits for farmers if it led to oligopsonic or monopsonic structure, atomizing further the latter who as a result would be left with little, if any, room for negotiating remunerative prices for their output.

\subsection{Price Linkages between Domestic and Global Cocoa Markets and Trade Reforms: Theoretical Underpinnings}

Trade has arguably been considered the key to explaining the linkage between domestic and world markets of agricultural products. If a specific commodity is exported and traded in world markets, the prices received by domestic producers equal the international price minus transaction costs (Rapsomanikis et al., 2006). The assumption of price transmission from world to domestic markets for agricultural products is common in the literature (Baffes and Gardner, 2003; Sharma, 2003). The main argument is that the atomized nature of farmers compared with global 
agricultural commodity markets reduces them to price takers. In other words, these farmers are almost entirely at the mercy of price movements in international markets. This is particularly true for cocoa markets where buyers usually use prices in world markets as reference when sourcing cocoa beans from farmers, who usually after harvesting the pods, ferment and dry the beans on their farms or in their villages.

Historically, the marketing of cocoa beans from farm gates to export markets was controlled by national commodity boards. The boards would purchase the beans from farmers through collection points near villages, and act as principal sellers and exporters. Today, wherever the domestic cocoa market is liberalized, farmers directly sell their crops at buying stations to export agents or brokers. In all the cases, including in deregulated or non-deregulated markets, the buyers offer farmers prices that reflect the prevailing prices of cocoa beans in international cocoa markets (ITC, 2001). These markets include the London International Financial Futures and Options Exchange (where prices are denominated in British pound) and New York-based Intercontinental Exchange (where prices are set in United States dollars). These markets offer standardized futures contracts for cocoa beans with commitments to trade given quantities of cocoa at a certain price at the expiry of the contracts. The delivery ports of these contracts are located in Europe or the United States.

The business profitability of cocoa trading implies that farm gate prices of cocoa remain below world prices. The spread between the two prices contributes to covering the expenses incurred by traders from moving the beans from farms to delivery ports in importing countries. These expenses include inland and international transportation fees, taxes and other duties, storage costs at the ports of producing countries and the profit margins of traders (Cocoa Barometer, 2015) as illustrated in Figure 2. Moreover, farm gate prices of cocoa are denominated in the national currency of production countries, whereas the prices in world markets are set in international currencies. Therefore, volatility in the exchange rates in producing countries affect the prices paid to cocoa farmers.

The transmission channels depicted in Figure 2 also imply that improvement in domestic marketing channels (lower transactions costs including transport fees, reduced taxes and duties, higher bargaining power of farmers) would contribute to increasing the prices paid to cocoa farmers. These improvements were partly expected to be achieved through trade liberalization reforms under structural adjustment programmes undertaken by most developing countries in the 1980s and the 1990s.

Some key objectives of the trade reforms were the elimination of trade barriers, increased competition in the cocoa marketing channels and reduction in regulatory burdens that would result in higher prices paid to local producers including farmers (Ajetomobi, 2014; Gilbert, 2009). Before these reforms, parastatal entities were controlling national cocoa markets in producing countries. These entities set farm gate prices and buyers margins while collecting export taxes (Fold, 2002). Although the raison dêtre of the parastatal agencies was to isolate farmers from volatility in global cocoa markets, an unintended consequence of their operations was that prices paid to farmers over time diverged greatly from price trends in international markets as a result of high taxes, and mismanagement in several cases (Rapsomanikis et al., 2006; Sharma, 2003; Williams, 2009). Trade liberalization entailed, therefore, the elimination of the parastatal entities and promotion of private institutions and market agents that were to make the marketing channel more efficient, with induced gains passed on to farmers. Yet, the extent to which the trade reforms, some three decades later, have achieved their expected outcomes is still debatable. This study contributes to this debate.

\section{THE MODELLING FRAMEWORK AND VARIABLE DESCRIPTION}

This section discusses the conceptual framework of the study, including the model, used for the empirical analysis. It specifically provides an overview of the previous studies on price transmission analysis in agricultural commodities markets. It also presents the empirical model used in this paper and describes the variables.

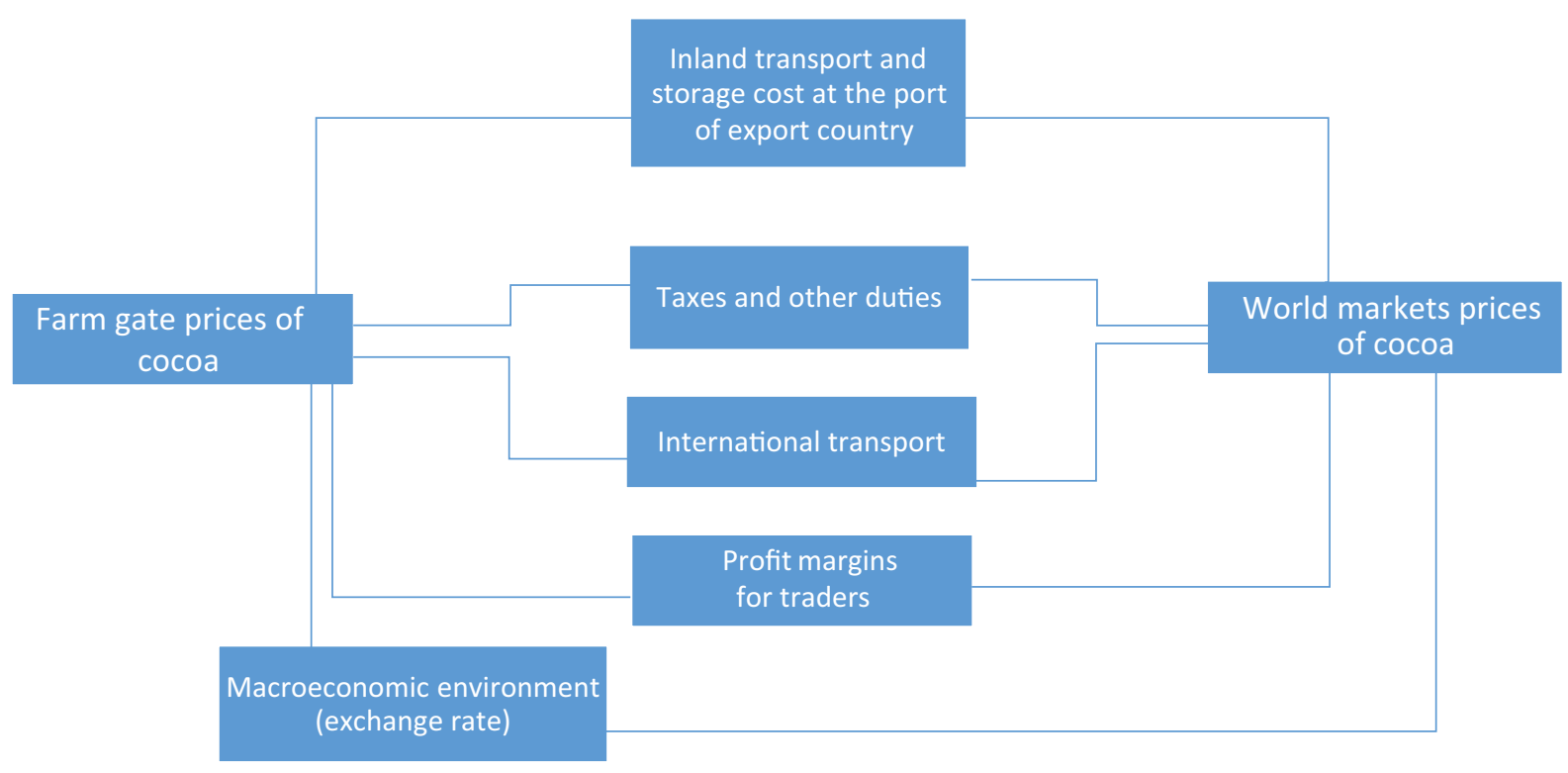

Figure 2 Transmission channels between farm gate and international prices of cocoa. 


\subsection{Price Transmission and Market Integration for Agricultural Products: Literature Overview}

A number of studies have analysed price transmission dynamics in agricultural commodity markets. Quiroz and Soto (1995); Mundlak and Larson (1992) assessed transmission of price signals from world markets to producers using the Food and Agricultural Organization (FAO) of the United Nations annual price data. The former covered 78 countries over the 1966-1991 period, with between four and 15 products per country, and found non-existent or extremely low price transmission in 60 countries. By contrast, the latter used data on 58 countries over the 1968-1978 period covering 60 agricultural products and concluded that the variations in world price constitute the dominant component in the domestic price changes.

More recently, commodity price transmission analysis based on time series techniques has been carried out within the context of trade policy reforms with mixed results so far. Baffes and Gardner (2003) examined the degree to which world prices have been transmitted to domestic prices for eight countries and 10 commodities under trade policy reforms. They found that the effect of the reforms on world and domestic markets integration varies by countries and commodities. Markets integration was found to be significant in some cases and was either low or non-existent in others due primarily to national trade policies. Shepherd (2004) analysed price transmission through the coffee processing chain at a global level. He concluded that trade liberalization reforms have not significantly improved price transmission but rather have worsened it in some respects. The author attributed the cause of this to market power being potentially exerted by buyers in a context of high concentration of actors in the coffee GVC. Worako et al. (2008) investigated producer and world price transmission mechanism in Ethiopian coffee market. They concluded that domestic prices of coffee adjusted more rapidly to world price changes after the country had implemented trade policy reforms. However, the authors stressed that impacts of the reforms on the levels of prices received by Ethiopian coffee farmers have been limited by a number of market failures including lack of adequate market information system, high marketing and transaction costs, collusion among buyers and high concentration of exporters. Ajetomobi (2014) investigated the issue of market integration through price transmission in Nigerian cocoa markets over the postliberalization period, and concluded that market liberalization improved the efficiency of the country's cocoa marketing channels.

Against this backdrop, this paper specifically investigates price transmission from world cocoa markets to farmers in the following key producing countries: Cameroon, Côte d'Ivoire, Ecuador, Ghana and Indonesia. As discussed earlier, the choice of the countries is guided by availability of quality data, the importance of the country in cocoa production at continental levels and the significance of the cocoa sector in their economies.

\subsection{Empirical Model}

The empirical framework is based on the ECM described later. ${ }^{4}$ Consider $y_{t}$ and $x_{t}$ as the annual producer and world prices of cocoa, respectively, expressed in logarithmic value. The relationship between the two prices may then be written as follows [Equation (1)]:

$$
y_{t}=\propto+\beta x_{t}+u_{t}
$$

where $u_{t}$ is the error term and $\beta$ represents the long-term elasticity between the prices. A necessary condition to conclude that a producer price is strongly related to the world price of cocoa in the long run requires that $y_{t}$ and $x_{t}$ be co-integrated, ${ }^{5}$ meaning that [Equation (2)]

$$
u_{t}=y_{t}-\beta x_{t}
$$

is a stationary process. If the two price series are co-integrated, the producer price is said to be in a stable and long-run equilibrium with the world price of cocoa. The relationship may then be estimated through the following [Equation (3)]:

$$
\Delta y_{t}=\theta_{0}+\theta \Delta x_{t}+\gamma u_{t-1}+v_{t}
$$

where $\theta_{1}$ gives the short-run relationship between the variation of $y_{t}$ and that of $x_{t}$ and the coefficient $\gamma$ measures the long-run adjustment of $y_{t}$ to $x_{t}$. Indeed, $\gamma$ is a measure of the speed of convergence, that is, the extent to which a disequilibrium in the two series in the previous period (previous crop year, for example, in the case of cocoa annual prices) is corrected in the current period (current crop year).

The existence of a short-run relationship implies that producer prices adjust immediately, that is, during the same period, to signals of world price. A short-run coefficient of one means that shocks in the world cocoa market are completely transmitted to national market during

\footnotetext{
${ }^{4}$ Beyond the ECM which provides a sound framework in assessing price transmission from world to domestic commodity markets (Baffes and Gardner, 2003; Worako et al., 2008), the Vector Error Correction Model (VECM) is often considered a superior technique, as it has several advantages. First, the VECM, unlike the ECM which is a single equation

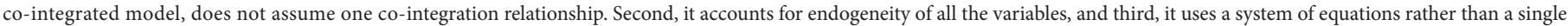
equation to estimate the model (Johansen and Juselius, 1990; Rapsomanikis et al., 2006). These notwithstanding, the ECM is used in this study instead of VECM for two main reasons. First, the period covered by the series of annual cocoa farmer prices differs throughout the selected five countries. This could not correctly fit into the VECM framework. Second, the

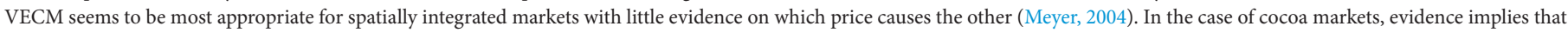

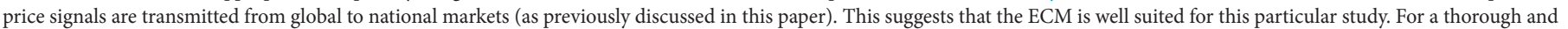
extensive review of co-integration and error correction modelling, see, for example, (Maddala and Kim, 1998; Rapsomanikis et al., 2006).

${ }^{5}$ For a thorough and extensive review of co-integration and error correction modelling, see, for example, (Maddala and Kim, 1998; Rapsomanikis et al., 2006).
} 
the same crop year. A significant long-run adjustment coefficient would suggest existence of a long-term equilibrium relationship between producer and world cocoa prices. In other words, the two prices track closely with each other in the long run, although they can drift apart in the short run. The overall adjustment proportion $(k)$ of producer price to a given change in world price after $n$ periods may be obtained through the following formula: $k=1-(1-\theta)(1-\gamma)^{n}$ (see Baffes and Gardner, 2003).

To consider the impact of possible structural breaks such as the introduction of trade reforms that might have affected the relationship between the two prices, a dummy variable is introduced in a multiplicative form in the Equations (1) and (3) as in Worako et al. (2008). This multiplicative dummy also permits to estimate a pooled regression with one equation instead of two distinct equations. The main advantage is that a pooled regression increases observations, yielding greater degree of freedom.

The dummy variable is also added to Equation (1) in an additive form to capture possible changes in the constant term before and after the reform periods. Denoting the dummy as $d_{t}=1$ for prices obtained during the period after the introduction of reforms and zero otherwise, a pooled regression form of Equation (1) becomes Equation (4)

$$
y_{t}=\alpha_{0}+\rho d_{t}+\alpha_{1} x_{t}\left(1-d_{t}\right)+\alpha_{2} x_{t} d_{t}+u_{t}
$$

With this formulation, the constant terms and coefficients $\alpha_{i}(i=1,2)$ differ from the pre- and postreform periods. The coefficients $\alpha_{i}(i=$ $1,2)$ represent, respectively, the long-term elasticity between producer and international prices before and after reform periods.

With the introduction of the dummy variables, the equivalent of the ECM in Equation (3) is Equation (5)

$$
\Delta y_{t}=\theta_{0}+\theta_{1} \Delta x_{t}\left(1-d_{t}\right)+\theta_{2} \Delta x_{t} d_{t}+\gamma_{1} u_{t-1}\left(1-d_{t}\right)+\gamma_{2} u_{t-1} d_{t}+v_{t}
$$

Coefficients $\theta_{i}(i=1,2)$ describe the short-run effect of the variation in producer and world price, respectively, before and after the reforms were introduced, whereas $\gamma_{i}(i=1,2)$ capture the speed of adjustment to equilibrium prices before and after reform periods, respectively. Equation (5) may be extended to capture any asymmetry in the short-run relation between producer and world cocoa prices.

Assessing potential asymmetry in the price transmission implies investigating whether producer prices react in the same manner for both increases and decreases in world price of cocoa. The investigation of the prevalence of asymmetric price transmission from world to domestic markets in the short-run is underscored by several potential arguments. One argument relates to market concentration and noncompetitive price behaviour. This argument posits that in the presence of market power derived from market concentration and imperfect competition, as is the case in cocoa markets (Gayi and Tsowou, 2016), the transmission of an increase in world prices of tradable products to producers is weaker than that of a decrease in prices (Scherer and Ross, 1990). A second argument for asymmetric price transmission relates to national trade policies such as floor price policy (Rapsomanikis et al., 2006). In the case of cocoa, this may be derived from the minimum guaranteed price set for cocoa farmers in producing countries such as Cote d'Ivoire and Ghana, which may insulate producer prices from downward swings in world price. Asymmetric price transmission may also be partly driven by inventory holding behaviour (Maccini, 1978). Indeed, in domestic cocoa markets, expectations of high prices in world markets or high indicative prices set by government in domestic markets may lead to stock accumulation locally. When high prices are recorded as expected, release of stocks may exert downward pressure on local markets and cause producer prices not to rise as much as it would in the absence of inventories.

Technically, the asymmetric effect may be captured by introducing a dummy that describes a price increase or decrease. Denoting the dummy $D_{t}=1$ for an increase in world price (i.e., $\left.\Delta x_{t} \geq 0\right)$ and $D_{t}=0$ for a decrease in world price (i.e., $\left.\Delta x_{t}<0\right)$, Equation $(5)$ becomes Equation (6)

$$
\Delta y_{t}=\theta_{0}+\theta_{1} \Delta x_{t}\left(1-d_{t}\right) D_{t}+\theta_{2} \Delta x_{t}\left(1-d_{t}\right)\left(1-D_{t}\right)+\theta_{3} \Delta x_{t} d_{t} D_{t}+\theta_{4} \Delta x_{t}\left(1-D_{t}\right) d_{t}+\gamma_{1} u_{t-1}\left(1-d_{t}\right)+\gamma_{2} u_{t-1} d_{t}+v_{t}
$$

Coefficients $\theta_{i}(i=1-4)$ describe the short-run responses of producer prices to increase and decrease in world price, respectively, before and after reforms.

\subsection{Data and Sources}

The study is mainly based on statistics from database and publications of the FAO, the International Cocoa Organization (ICCO) and the World Bank. Although in some cases, where more information was needed, or gaps in the information flow were found, interviews were conducted with key informants by telephone or e-mails.

The ICCO annual cocoa beans price, expressed in United States Dollar per ton, is used as a proxy of world cocoa price. The producers' prices came from (FAO, 2016). The period covered by data, depending on their availability, varies with countries, although not much: Cameroon (1966-2010), Côte d'Ivoire (1966-2009), Ghana (1966-2011), Ecuador (1966-2012) and Indonesia (1967-2012). Nominal prices in national currencies are converted into the United States Dollar using annual average exchange rates from the World Bank (World Development Indicator) to facilitate comparison before they were transformed into natural logarithm. 


\section{MODELLING RESULTS AND DISCUSSION}

The analysis, based on the ECM framework described earlier, is carried out after stationarity testing which is a key step in time series modelling. ${ }^{6}$ The inclusion, in the modelling section, of a dummy variable which captures the adoption of trade policy reforms is based on information provided in Table 1 (also see Section 2, The Cocoa Markets and Trade Liberalization). Nevertheless, the ECM framework does not permit distinguishing between specific factors which affect the dynamics of price transmission between domestic and world cocoa markets. Therefore, we attempt to complement our discussions by comments on factors that could possibly affect the price transmission in each country.

\subsection{Stationary Tests and Co-integration Relation}

The results of stationary tests-Phillips-Perron and Augmented Dickey-Fuller-are provided in Table 2. The price variables are nonstationary in levels but become stationary after first difference. These imply that world and producer prices of cocoa could have a long-term relationship if their linear combination is stationary. This is formally assessed through co-integration tests with break dates relative to trade policy changes which might have affected internal cocoa marketing in producing countries.

The results of co-integration tests are provided in Table 3. They confirm the existence of a co-integration relation between the prices. The co-integration relation before trade liberalizing reforms may account for the fact that although producer prices were regulated in countries such as Cameroon, Côte d'Ivoire and Ghana before the reforms, producer prices were continuously adjusted to world price of cocoa by the commodity boards of each country. After the introduction of trade reforms, except for Indonesia, the relation between world and producer prices of cocoa improved as evidenced by the values of the long-term elasticity between world and producer prices for cocoa, which are higher during the period after the reforms compared with the period prior to the reforms. For example, a $1 \%$ increase in the world cocoa price resulted in a $0.80 \%$ increase in Cameroonian producer price before the reforms. After the reforms, the same proportion of increase in the price of world cocoa led to a higher (1.04\%) increase in the price paid to the country's cocoa producers. The equivalent values in Ghana are $0.90 \%$ for the pre-reform period and $1.05 \%$ for the postreform period. In Côte d'Ivoire and Ecuador, the increases are moderate from one period to other.

Table 2 Stationary tests for price variables

\begin{tabular}{|c|c|c|c|c|c|c|c|}
\hline & \multirow{3}{*}{ Period } & \multicolumn{4}{|c|}{ Price in level } & \multirow{2}{*}{\multicolumn{2}{|c|}{$\begin{array}{c}\text { Price difference } \\
\text { Without trend }\end{array}$}} \\
\hline & & \multicolumn{2}{|c|}{ With trend } & \multicolumn{2}{|c|}{ Without trend } & & \\
\hline & & ADF & PP & ADF & PP & ADF & PP \\
\hline World cocoa price & 1966-2012 & -2.8 & -2.28 & $-2.80^{*}$ & -2.37 & $-5.91^{\star * *}$ & $-4.51^{\star \star \star}$ \\
\hline \multicolumn{8}{|l|}{ Producer prices } \\
\hline Cameroon & $1966-2010$ & -1.94 & -2.11 & -1.47 & -1.41 & $-5.54^{\star * \star}$ & $-7.77^{\star * *}$ \\
\hline Côte d'Ivoire & $1966-2009$ & -2.25 & -2.15 & -2.26 & -2.13 & $-4.96^{\star * *}$ & $-6.57^{\star * *}$ \\
\hline Ecuador & 1966-2012 & -2.38 & -2.07 & -2.30 & -1.99 & $-5.08^{\star * *}$ & $-5.43^{\star \star \star}$ \\
\hline Ghana & $1966-2011$ & -2.12 & -2.06 & -1.90 & -1.86 & $-5.85^{\star \star \star}$ & $-6.307^{* * *}$ \\
\hline Indonesia & $1967-2012$ & -2.05 & -2.31 & -1.78 & -2.15 & $-4.61^{\star * *}$ & $-6.40^{* * *}$ \\
\hline
\end{tabular}

Note: Null hypothesis of unit root rejected at ${ }^{* *} 1 \%,{ }^{* *} 5 \%,{ }^{*} 10 \%$. ADF, Augmented Dickey-Fuller; PP, Phillips-Perron.

Table 3 Co-integration between world and producer prices of cocoa with structural break (pooled regression)

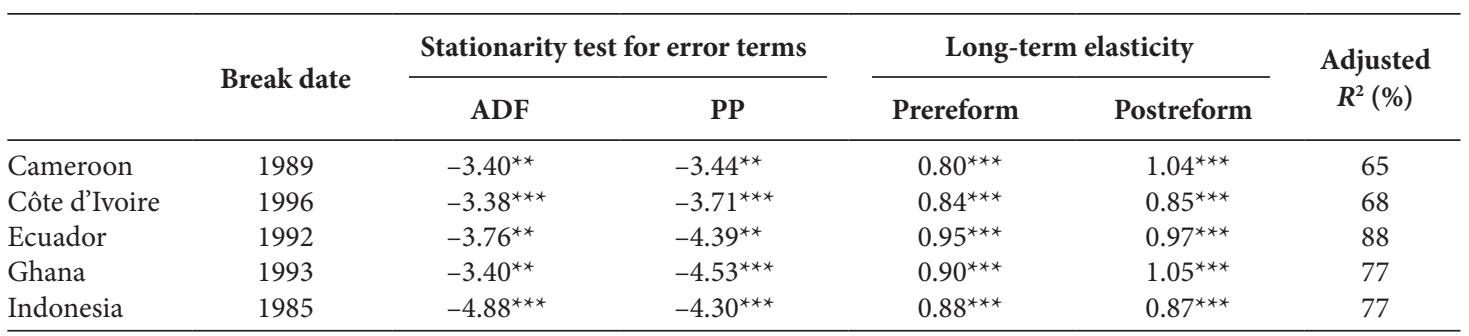

Note: Significance levels at ${ }^{* *} 1 \%,{ }^{*} 5 \%,{ }^{*} 10 \%$. ADF, Augmented Dickey-Fuller; PP, Phillips-Perron.

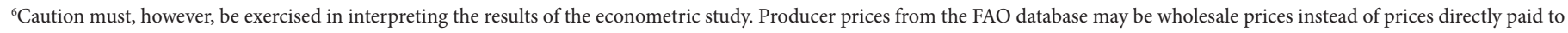

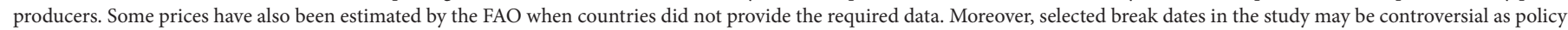

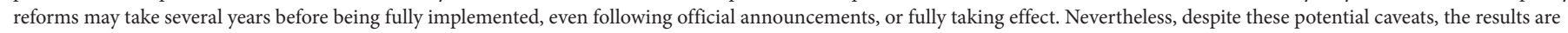
considered to be robust enough and the methodology appropriate to generate useful insights.
} 


\subsection{Results of Price Transmission}

The results of ECM accounting for short- and long-run relationships in the context of structural breaks are reported in Table 4 with mixed outcomes.

Short-run transmission from world cocoa markets to producers is not statistically significant for Cameroon and Ghana over the pre- and postreform periods, although it seems to increase with the reforms. In Indonesia, the postreform period has been associated with a nonexistent short-term relation between world and producer prices of cocoa. The situation in these countries could partly be attributed to market imperfections which delay the transfer of world market signals to domestic markets. These imperfections may include high transaction costs due to the poor state of rural infrastructure, market power of big players along the cocoa value chain and asymmetry in market information that usually prevails in developing countries, often to the detriment of small farmers. In the specific case of Ghana, the findings could also partly have resulted from high inflation and distortions in the country's exchange rate (Kolavalli and Vigneri, 2011) as well as the fact that even after trade reforms, the country's government has continued to play a significant role in the cocoa sector through a cocoa marketing board (Ghana Cocobod) which potentially acts as a buffer between farmers and global markets. Moreover, the cocoa producer price in Ghana is determined at the beginning of every crop year by the Producer Price Review Committee, a body consisting of Cocobod, government officials, representatives of private buyers and the national cocoa farmers' organizations. The producer price setting mechanism does not allow for adjustments in line with the rate of domestic inflation thereafter, which almost certainly leads to a wedge between producer prices and the world cocoa price during the same crop season. For Côte d'Ivoire, the short-run transmission mechanism became effective after the implementation of trade reforms which might have therefore contributed to improved efficiency in the country's domestic cocoa markets. The transmission effect in Ecuador is significant during the two periods, although it increased with the reforms. The results for Ecuador are not surprising per se due to historically weak government intervention in the country's cocoa sector. For Côte d'Ivoire and Ecuador more specifically, the coefficient of short-run transmission is roughly 1 during the postreform period, meaning that shocks in world price of cocoa during a crop year are fully passed to domestic markets during the same crop year.

The speed of adjustment to long-run equilibrium between producer and world cocoa prices is significant for all the countries. Except for Indonesia, the speed of adjustment increased notably with trade policy reforms. For Côte d'Ivoire especially, results show a significant degree of over adjustment (i.e., adjustment coefficient higher than 1) of long-run price signals after the reform period. In the case of Indonesia, relative stability in the speed of adjustment during the periods prior to, and after, reforms could be attributed to the national marketing channels which were already characterized by liberalized trade practices even before the reforms.

These results imply that producer prices of cocoa in countries such as Cameroon, Côte d'Ivoire, Ecuador and Ghana adjusted more rapidly to shocks in world price after the reforms. An illustration is given for Cameroon and Ghana (Figure 2). For example, in the case of Cameroon, for a given change in the world price of cocoa, the 1-year price adjustment is estimated at $40 \%$, during the period before trade liberalization reforms. After the reforms were introduced, the percentage of price adjustment increased to nearly $90 \%$. This notwithstanding, heightened speed of adjustment between the prices also implies that exposure of the cocoa farmers to world markets has increased with the reforms.

\subsection{Asymmetric Transmission between Cocoa Prices}

The prevalence of asymmetry in short-term price transmission is estimated and tested for the countries; and the results are reported in Table 5. The modelling takes into account the effect of policy reforms as well as the transmission of increases and decreases in world cocoa prices to producers. During the prereform period, significant short-term price asymmetry is found for Cameroon, Côte d'Ivoire, Ghana and Ecuador. For Indonesia, the prereform period is associated with significant transmission of increases in the cocoa world price to farmers, whereas no evidence is found for price decreases.

During the postreform periods, transmission of upward swings in world cocoa prices to farmers is found to be significant for three countries, namely, Côte d'Ivoire, Ecuador and Indonesia. However, the transmission of price decrease is significant only for two of these

Table 4 Error Correction Model with structural break (pooled regression)

\begin{tabular}{|c|c|c|c|c|c|c|}
\hline & \multirow{2}{*}{$\begin{array}{l}\text { Break } \\
\text { date }\end{array}$} & \multicolumn{2}{|c|}{ Short run effect } & \multicolumn{2}{|c|}{ Adjustment coefficient } & \multirow{2}{*}{$\begin{array}{c}\text { Adjusted } \\
R^{2}(\%)\end{array}$} \\
\hline & & Before reforms & After reforms & Before reforms & After reforms & \\
\hline Cameroon & 1989 & 0.075 & 0.18 & $-0.35^{\star \star \star}$ & $-0.87^{\star * *}$ & 47 \\
\hline Côte d'Ivoire & 1996 & 0.12 & $1.08^{* * *}$ & $-0.40^{\star * *}$ & $-1.06^{\star * *}$ & 60 \\
\hline Ecuador & 1992 & $0.76^{\star * *}$ & $1.12^{\star * *}$ & $-0.48^{\star}$ & $-0.85^{\star *}$ & 67 \\
\hline Ghana & 1993 & 0.01 & 0.45 & $-0.61^{\star * *}$ & $-0.73^{\star * \star}$ & 40 \\
\hline Indonesia & 1985 & $0.33^{* *}$ & 0.21 & $-0.65^{\star * *}$ & $-0.63^{\star * *}$ & 41 \\
\hline
\end{tabular}

Note: Significance levels at ${ }^{* * *} 1 \%,{ }^{* *} 5 \%,{ }^{\star} 10 \%$. 
Table 5 Error Correction Model with structural break and asymmetric price transmission effect

\begin{tabular}{lllccccc}
\hline & Price movement & Periods & Cameroon & Côte d'Ivoire & Ecuador & Ghana & Indonesia \\
\hline & \multirow{2}{*}{ Price increase } & Prereform & -0.10 & 0.26 & $0.58^{* * *}$ & 0.18 & $0.55^{* * *}$ \\
& & Postreform & -0.10 & $1.17^{* * *}$ & $0.89^{* * *}$ & 0.69 & $0.60^{*}$ \\
Short-run transmission & & Prereform & 0.44 & -0.18 & $1.17^{* * *}$ & -0.51 & -0.17 \\
& \multirow{2}{*}{ Price decrease } & Postreform & 0.56 & $1.00^{* * *}$ & $1.39^{* * *}$ & 0.25 & -0.24 \\
& & Prereform & $-0.35^{* * *}$ & $-0.40^{* * *}$ & $-0.54^{*}$ & $-0.57^{* *}$ & $-0.68^{* * *}$ \\
Speed of adjustment & & Postreform & $-0.82^{* * *}$ & $-1.08^{* * *}$ & $-0.86^{* *}$ & $-0.61^{* * *}$ & $-0.67^{* * *}$ \\
\hline
\end{tabular}

Note: Significance levels at ${ }^{* * *} 1 \%, * * 5 \%, * 10 \%$.

countries, namely, Cote d'Ivoire and Ecuador. Where the transmission exists for both price increase and decrease, that is, in the cases of Côte d'Ivoire and Ecuador, we have not found any significant difference in the coefficients of asymmetry. ${ }^{7}$ These imply that transmission of an increase in the world price of cocoa to producers is not different from that of a decrease in these prices. A key implication is that farmers' exposure to world markets has increased with the reforms which have therefore made them more vulnerable to volatile international cocoa markets (Maurice and Davis, 2011) at the time when they have limited, or no, access to price risk management instruments.

Therefore, this empirical investigation fails to support the existence of market power in the marketing channels of cocoa beans in Côte d'Ivoire and Ecuador which might have prevented farmers in these countries from benefitting from increases in the world cocoa price while bearing much of the cost of price decline. However, this conclusion must be interpreted with caution as many other causal factors may have affected the asymmetric price transmission, as discussed earlier. For example, Griffith and Piggot (1994) found asymmetries in the Australian lamb and beef markets but not in pork market although the former is less concentrated than the latter. Moreover, the frequency (annual) of our data and the size of the sample for each country have limited the number of observations considered in assessing price asymmetries. Higher frequency data (e.g., weekly and monthly), deeper analysis of national market structure and the behaviour of various market participants would be needed to improve the price asymmetry analysis. This is, certainly, an area for future research.

When comparing the short-term transmission in the prices over the pre with postreform periods, the incidence of price swings in the world market is greater during the latter period. For example, in the case of Cote d'Ivoire, a 1 unit increase in the world price of cocoa resulted in an increase of 1.17 units in the producer prices after the reforms. Over the same period, a 1 unit decrease in world cocoa price resulted in a 1 unit decrease in the country's producer prices. Meanwhile, short-term price transmission was not found in Côte d'Ivoire before the reforms. These results are consistent with the previous findings: trade liberalizing reforms have increased cocoa producers' exposure to both positive and negative shocks in world markets.

The results so far first suggest that while the transmission of world to producer prices of cocoa varies by countries, overall, it seems to have increased with trade reforms. Short-term transmission of the prices improved significantly with the reforms in countries such as Côte d'Ivoire and Ecuador. By contrast, in Ghana and Cameroon, although the short-term price transmission seems to have improved with the reforms, it is not statistically significant. In Indonesia, the short-term transmission exists before the reforms but seems to weaken thereafter. The long-run adjustment of producer prices to world cocoa prices has increased with trade liberalizing reforms in all the countries examined, except for Indonesia where the relation remains relatively unchanged. In other words, cocoa farmers in the producing countries such as Cameroon, Côte d'Ivoire, Ghana and Ecuador are integrated (i.e., are linked) with world markets in the long run, and this integration has increased with trade liberalizing reforms. The findings also imply that producers became more exposed to the volatile world cocoa prices under the reforms. The extent to which these developments have been associated with the evolution in the share of producer prices relative to world price of cocoa is explored in the next section.

\subsection{Shares of Producer Prices Relative to World Price of Cocoa}

The empirical analysis suggests that trade liberalization reforms undertaken by cocoa producing countries in the 1980s and 1990s have generally improved price adjustment between their domestic and world cocoa markets. The reforms might thus have been considered successful if their sole objective was to induce better response of cocoa producer prices to changes in world market prices. Have the changes in price transmission attributable to the reforms impacted on the shares of the world price accruing to farmers? This is a key question considering that a major argument in favour of the reforms was that they would contribute to generating a higher share of international prices to cocoa farmers by linking the latter directly with buyers (Gilbert, 2009; Shepherd, 2004). With regard to this latter objective, the outcomes have been mixed so far, as evidenced by the evolution in the shares of producer prices relative to world price of cocoa in our sample of producing countries (Figure 3).

The shares of producer prices relative to the world price of cocoa vary within and across countries. In Côte d'Ivoire, for example, the postreform period has not been associated with a higher share of cocoa prices accruing to farmers. The average share of world price paid to Ivorian producers fell from roughly $70 \%$ during the period $1986-1990$ to $54 \%$ over the first half of 1990 s (i.e., before the reforms).

${ }^{7}$ We have formally assessed through F-tests (the results are not reported here, but may be provided on request) whether increase or decrease in the world price of cocoa has the same incidence on producer prices in Côte d'Ivoire and Ecuador. 

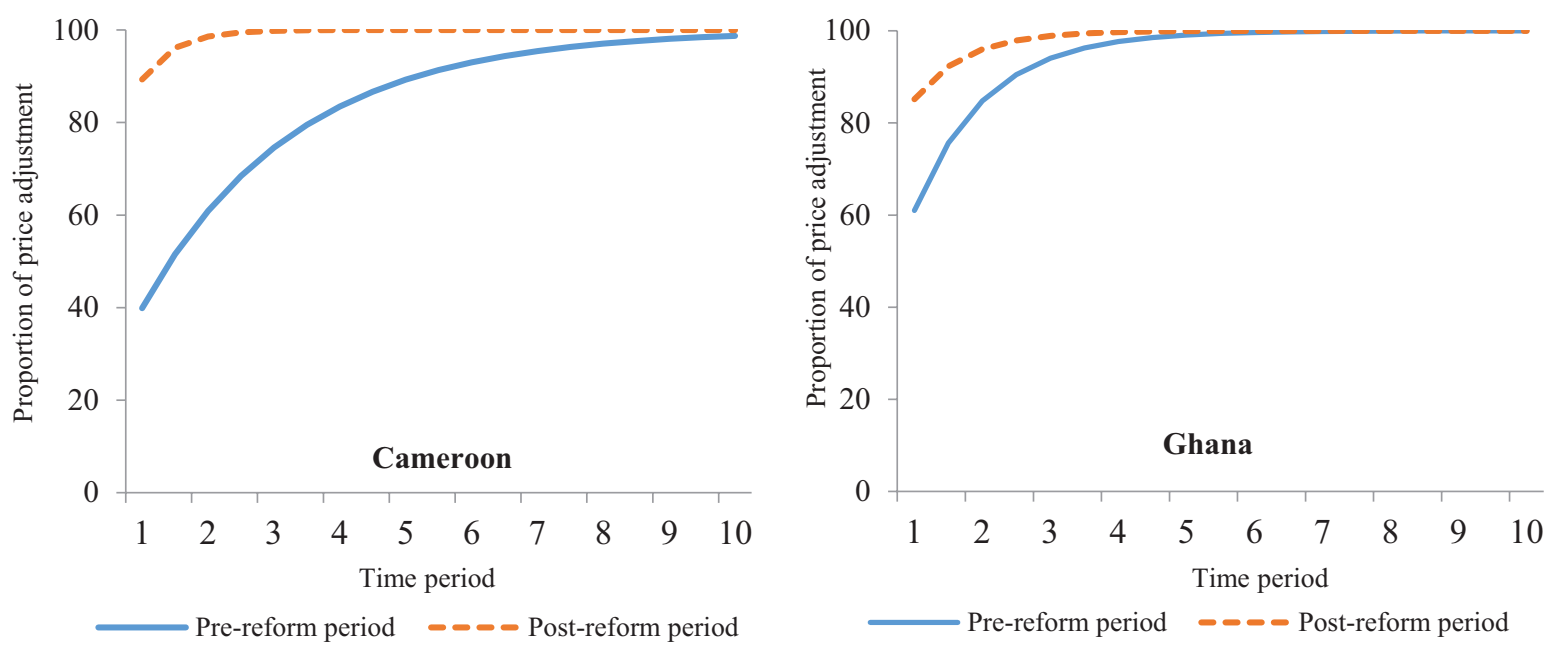

Figure 3 Speed of price adjustment in Cameroon and Ghana over the pre-reform and postreform periods. Note: Vertical axis depicts the percentage of adjustment of domestic prices to a given change in world price after $n$ periods (horizontal axis). The adjustment proportion ( $k$ ) of producer price to a given change in international prices after $n$ periods is calculated according to the following formula: $k=1-(1-\theta)\left(1-\gamma^{n}\right.$ (Baffes and Gardner, 2003, p. 162).

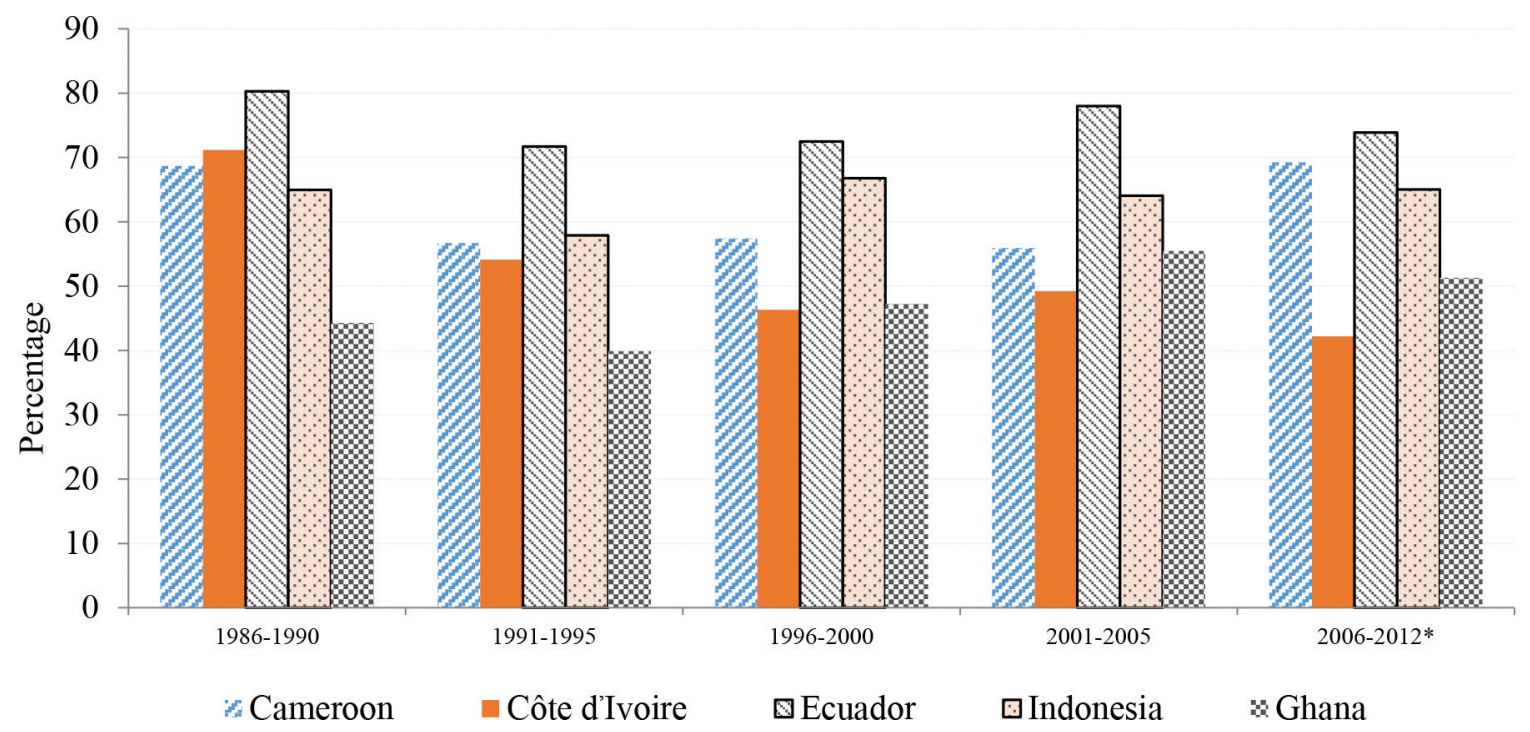

Figure 4 Cocoa producer prices as a percentage of world price in selected countries. ${ }^{*}$ Note: Data fully covering the sub-period $2006-2012$ were not available for all the countries. Data coverage for this sub-period is as follows: Cameroon: 2006-2010, Côte d'Ivoire: 2006-2009; Ghana: 2006-2011; Ecuador and Indonesia: 2006-2012.

Despite the reforms, it declined further and remained below 50\% over the period 1991-2009. In Ghana, the share accruing to farmers increased in the 2000s compared with the 1990s, albeit it remained relatively low (between 50\% and 55\%) from 2001 to 2011. By contrast, in Cameroon, Ecuador and Indonesia, cocoa farmers received a relatively higher share of world price, especially after 2000. Ecuadorian cocoa farmers, for example, received more than 70\% of world cocoa prices over the period 2001-2012.

The contrasting evolution in the shares of producer prices relative to the world price of cocoa confirms that the prices received by farmers are influenced by domestic factors. In Cameron, reduced taxes on cocoa beans exports might have contributed to higher prices paid to cocoa farmers (UNCTAD, 2008). In the case of Ecuador, higher prices paid to farmers have been driven by low export taxation, the establishment of minimum reference prices for cocoa beans and high quality of the beans produced in the country (Ton et al., 2008; WTO, 2005; WTO, 2011). Moreover, the fact that Ecuador is a dollarized economy has possibly contributed to keep the country's producer prices higher compared with other cocoa producing countries where unfavourable exchange rates might have negatively affected the prices paid to farmers. In Côte d'Ivoire, domestic factors may explain why strong price transmission signals between domestic and world cocoa markets after trade reforms are associated with low share of producer prices relative to the world price of cocoa. In fact, the country's domestic cocoa sector is still subject to high taxation, estimated, for example, at between $25 \%$ and $30 \%$ over the period 2002-2009, which has contributed to the downward pressure on prices paid to the country's cocoa farmers (Kireyev, 2010). Other potential factors in the case of Côte d'Ivoire include political instability in the country from 2002 to 2010 (Gilbert, 2009) as well as market power exerted by multinational exporters or processors on cocoa farmers (Kireyev, 2010). In Ghana, low prices received by cocoa farmers have been partly attributed to high levels of 
inflation and overvalued exchange rate (Gilbert, 2009; Kolavalli and Vigneri, 2011). The case of Ghana is evidence of the extent to which the macroeconomic policy stance of a country can impact on prices paid to farmers. Indeed, the country's Cocobod, under improved management, good governance and accountability after it was reformed, has enabled farmers' to improve productivity and increase producer prices (Williams, 2009). Nevertheless, a major impediment to the country's cocoa sector remains, that is, an unfavourable monetary policy environment with high inflation and overvalued exchange rates, which significantly erodes farmers' incomes and as a result reduces the share of world cocoa prices accruing to them.

A number of other market imperfections could also explain the low prices received by cocoa farmers in the key producing countries at a time when trade reforms have improved their linkage with world markets. For example, the oligopsonic structure of national marketing channels in cocoa producing countries (Ecobank, 2012) could be detrimental for fragmented small-scale farmers, albeit empirical evidence of market power exerted by buyers has been inconclusive on this point (Anang, 2011; Traoré, 2009; Wilcox and Abbot, 2004). The main argument is, however, that this kind of market structure increases the risk of anticompetitive practices, creating a favourable environment for tacit or formal collusive behaviour by the big players (Losch, 2002, p. 225, Kaplinsky, 2004, p. 29) as has happened in other agro-food industries (Shepherd, 2004; Dobson et al., 2001; Goodwin, 1994). In the domestic markets of cocoa producing countries, the situation could have resulted in low prices paid to farmers who are entrenched in a weak bargaining position due to their scattered and unorganized nature. Low prices paid to cocoa farmers could also result from the number of intermediation levels between farm gate and the export point. In some cases, farmers have to deal with a large number of small- and medium-sized intermediaries, who often work for large-sized intermediaries in the domestic marketing channels. Subsequently, the margin available for farmers is very low as each intermediary tends to capture a share of profits that could have been passed onto farmers if the latter had direct access to exporters. This situation is almost certainly exacerbated by the poor state of transport infrastructure prevailing in the rural areas of many cocoa producing countries which increases transaction costs for traders and therefore discourages them from paying higher prices to farmers. Moreover, the poor access of farmers to financial and market information also affects their negotiation power, weighing down on the prices they receive from selling their products. For example, poor access to credit has led cocoa farmers in Cameroon to enter into partnerships with traders who provide them with the money they need during the planting season in exchange for their crops, often on very unfavourable terms for the farmers (Kamdem et al., 2010).

The discussion in this section reveals how the characteristics of domestic markets could affect cocoa farmers' incomes. More detailed country case studies would, however, be required to identify specific determinants of domestic markets that are affecting cocoa farmers' prices. This notwithstanding, the analysis carried out so far provides sufficient insights to discuss some policy options that could help in improving farmers' situation so as to promote a sustainable cocoa farming.

\section{CONCLUDING REMARKS: WHAT ARE THE KEY POLICY IMPLICATIONS OF THIS STUDY?}

This study analyses the extent of integration of cocoa farmers into international markets through an assessment of the transmission of the world cocoa price to farmers, that is, the prices the latter receive. The transmission, where there is some evidence to support it, has increased with trade liberalization reforms undertaken by cocoa producing countries in the past two or three decades. The reforms have particularly increased farmers' long-run exposure to the vagaries of international markets, but they are not systematically associated with a significant, if any, increase in the share of world prices of cocoa accruing to farmers, especially in a major producing country such as Côte d'Ivoire.

These findings point to some interesting observations. First, a better adjustment of cocoa producer prices to the international cocoa price through trade liberalization reforms does not guarantee higher prices to farmers. Second, many factors that are specific to domestic markets affect the prices received by cocoa farmers. Some of the factors that might have played against farmers' interests, weighing down producer prices, possibly include distorting national trade policies such as high taxes on cocoa exports, the oligopsonic structure of national marketing channels resulting in weak bargaining position of farmers, weak or lack of adequate access to market information as well as high transactions costs.

To promote a sustainable cocoa economy in which small farmers play an invaluable role, an important issue to address is certainly how these farmers could capture a higher share of the total value generated along the cocoa GVC. A major finding in this paper is that domestic markets are not functioning that well for cocoa farmers. As a result, the share of the price they receive from selling their output compared with that prevailing in international markets is low, especially in key producing countries such as Côte d'Ivoire and Ghana. For these countries and others, supporting cocoa farmers' businesses cannot be overstated. To be able to produce efficiently and improve their earnings so as to sustain themselves and their families, cocoa farmers should be paid a price for their beans that not only covers their costs of production but also enables them to realize what could be considered a fair profit margin.

The earlier discussions suggest that some key issues have to be addressed if cocoa farmers are to improve their profitability which is partly determined by the price they receive from selling their crops. ${ }^{8}$ In this section, we contend that in a context where trade liberalization reforms have increased the exposure of farmers to the vagaries of the world cocoa market, there is a need to address domestic market imperfections to enable farmers derive optimal benefits from the reforms. Therefore, enabling policies would be necessary to enhance the efficiency of domestic markets in cocoa producing countries. These should provide opportunities for increasing the incomes of farmers. The set of required policies should address domestic market inefficiencies by promoting competitive marketing channels and ensuring transparency among all the stakeholders in the cocoa sector, as well as lowering transactions costs. This set of policies should also contribute to increasing the levels of producer prices.

${ }^{8}$ Another key determinant of profitability for cocoa farming is productivity. However, this aspect is beyond the scope of this paper. 


\subsection{Promoting Competitive Domestic Markets}

As discussed earlier, the current oligopsonic structure of domestic cocoa markets results in power imbalances between highly integrated big players and other stakeholders, particularly farmers. In a major cocoa producing country such as Côte d'Ivoire, this situation might have been partly responsible for farmers not being able to capture a higher share of international prices although we found a complete transmission of price signals from world to the country's domestic cocoa markets. If this market structure prevails unchecked, it will effectively undermine competition in the domestic cocoa market, adding further downward pressure on the price paid to farmers. The main arguments here are that a limited number of traders not only create a favourable environment for anticompetitive practices, but almost certainly reduce the bargaining room for fragmented farmers. As a result, the latter would not be able to bargain for higher and fairer prices for their output.

Creating a level playing field, by ensuring a competitive domestic cocoa market, is therefore critical to reversing the low prices received by cocoa farmers. Typically, this would entail a number of measures. First, it is imperative to enact, or reinforce, competition law in cocoa producing countries so as to prevent anticompetitive practices and limit market power of trading or processing companies which source beans from farmers. For this group of countries, the challenge with respect to competition laws is at two levels: how to enact and enforce these laws and how to address the challenge faced by legislators due to the 'extraterritorial characteristic' of national markets which stems from the fact that major TNCs active in cocoa trading or processing do not fall under the jurisdiction of cocoa producing countries. The former challenge could be addressed by improving institutional capacities at national levels with strong competition agencies. For the latter challenge, it would almost certainly require harmonization of rules dealing with anticompetitive practices, as well as cooperation among competition agencies at the global level with effective supervision by an international body.

Second, competitive domestic cocoa markets would require a supportive environment for local small participants, such as small traders and grinders, to remain in business. Indeed, key drivers of high concentration of buyers in the domestic markets of cocoa producing countries are the obstacles faced by local small participants to compete on a level playing field with TNCs, as the latter have better access to resources such as finance and technologies (ACET, 2014; Gilbert, 2009). Therefore, keeping local stakeholders including local small- and medium-sized enterprises involved in the national cocoa value chain would entail addressing the high costs of finance and high taxes on cocoa trading and processing activities in producing countries (ACET, 2014; Ecobank, 2014). In addition, keeping these local stakeholders in business would help to improve the value-added activities locally, which in turn could result in higher prices paid to cocoa farmers. For example, in Malaysia, thanks to a package of incentives, including an investment tax allowance, or partial tax exemption, for local players, several local entrepreneurs are directly involved in the cocoa sector; this contributes to improve the value-added activities retained by local cocoa communities (ACET, 2014). This is a good example of relevant policy that could be replicated elsewhere.

\subsection{Ensuring Greater Transparency in Domestic Cocoa Markets}

Agricultural markets in developing countries are often not transparent to farmers as they encounter difficulties in accessing reliable market information on demand, prices and quality, whereas buyers have usually better access to such information (Deardorff and Rajaraman, 2009). In the case of cocoa, this asymmetry which tends to favour traders is probably a major reason for the weak transmission of price signals from the world to domestic markets for some key cocoa producing countries, such as Cameroon and Ghana. Where high price transmission was found, as in the case of Côte d'Ivoire, weak access to market information that prevents farmers to enquire, for example, about market prices at national or international levels could also explain how the country's cocoa farmers receive relatively low shares of world cocoa prices. A supporting argument is that a lack of market information may force small farmers to rely on intermediaries. The latter, which usually have better information on market prices compared with farmers, may use this information asymmetry to their advantage, offering producers low prices that might not reflect urban or international market prices. Thus, transparent markets for all the actors in the domestic cocoa sector would allow farmers to gain better access to information to make optimal marketing decisions. In Cameroon, for example, improved access to market information has contributed to enhancing the capacity of cocoa farmers to negotiate better prices for their beans (Wilcox and Abbott, 2006).

Governments in cocoa producing countries should therefore promote appropriate investments in new information and communications technologies through public and private partnership as a means of facilitating and enhancing farmers' access to market information. Several successful examples exist in developing countries. The CocoaLink pilot project in Ghana involved at its pilot stage was a collaboration between the World Cocoa Foundation, the World Education, the Ghana Cocoa Board and the Hershey Company. This initiative helped to provide timely marketing, farming and social information (e.g., good farming practices, disease prevention, postharvest handling, crop marketing, farm safety and child labour issues) to Ghana's cocoa farmers through SMS text and voice messages. Another successful agricultural market information system, which is not, however, a purely cocoa-linked initiative, is Esoko. Launched in 2005, with funding from international donors, Esoko is now a profit-making business entity with private investors providing agricultural information services to farmers in countries such as Ghana and Kenya. These success stories and others which have contributed to improving farmers' access to information should be shared and replicated elsewhere, taking into consideration the specificities of each community.

\subsection{Lowering Transactions Costs in Domestic Markets}

High transactions costs resulting from impediments to trade such as the poor state of road transport, logistics and communication services in cocoa producing countries, particularly in those in Africa, could also contribute to explaining the relatively low levels of producer prices 
(Badiane and Shively, 1998; Njoh, 2008). These high costs erode the margins for buyers who in turn end up paying farmers a price which does not reflect world market price levels. The situation is often worse during the rainy season when roads in rural areas are hardly passable, making it more difficult for farmers and traders to get significant benefits from their trading activities. The problem becomes more acute when the distance from farm gates to markets is long, as is often the case in many developing areas.

These issues have endured in a number of cocoa producing countries, despite the recognition from governments that they impact negatively on the efficiency of domestic markets. The role of governments in providing public goods, such as roads, remains crucial, but given their limited financial resources, and in several cases, expertise, there is room for the engagement of the private sector through public and private partnerships.

\section{CONFLICTS OF INTEREST}

The authors declare no conflicts of interest. This paper represents the personal views of the authors only, and not those of their organizations.

\section{ACKNOWLEDGMENTS}

The authors express their gratitude to Professor John Struthers (University of the West of Scotland), Janvier Nkurunziza (UNCTAD) and Philippe A. Cobbina (Ghana Institute of Management and Public Administration) for their helpful comments. The authors also thank an anonymous referee and Professor Augustin FOSU for their various comments which have contributed to improving the quality of this paper.

\section{REFERENCES}

ACET, 2014. The cocoa agroprocessing opportunity in Africa [Internet], in: Background Paper Prepared by Dalberg Global Development Advisors and Commissioned by ACET for the 2014 African Transformation Report, African Center for Economic Transformation. http://africantransformation.org/wp-content/uploads/2014/02/2014-african-transformation-report.pdf (accessed July 13, 2015).

Ajetomobi J.O., 2014. Post-liberalization markets, export firm concentration, and price transmission along Nigerian cocoa supply chains, in: AGRODEP Working Paper 0005. http://www.ifpri.org/publication/post-liberalization-markets-export-firm-concentration-and-pricetransmission-along (accessed July 15, 2015).

Anang B.T., 2011. Market structure and competition in the Ghanaian cocoa sector after partial liberalization, Curr. Res. J. Soc. Sci. 3, 465-470.

Badiane O., Shively G.E., 1998. Spatial integration, transport costs, and the response of local prices to policy changes in Ghana, J. Dev. Econ. 56, 411-431.

Baffes J., Gardner B., 2003. The transmission of world commodity prices to domestic markets under policy reforms in developing countries, Policy Reform 6, 159-180.

Cocoa Barometer, 2015. Looking for a Living Income. A Joint Initiative of the VOICE Network [Internet]. https://www.voicenetwork.eu/wpcontent/uploads/2019/07/Cocoa-Barometer-2015-Print-Friendly-Version.pdf (accessed July 15, 2015).

Deardorff A.V., Rajaraman I., 2009. Buyer concentration in markets for developing country exports, Rev. Dev. Econ. 13, $190-199$.

Dobson P.W., Clarke R., Davies S., Waterson M., 2001. Buyer power and its impact on competition in the food retail distribution sector of the European Union, J. Ind. Compet. Trade 1, 247-281.

Ecobank, 2012. Structure and competition in West Africa's cocoa trade [Internet], in: World Cocoa Conference, Abidjan, Côte d'Ivoire, November 19-23. http://www.ecobank.com/upload/2013100804104885683757w49rm2gK.pdf (accessed March 11, 2015).

Ecobank, 2014. The Impact of Reform on Côte d'Ivoire's Cocoa Grinding Sector [Internet], in: World Cocoa Conference, Amsterdam, the Netherlands, June 9-13. http://www.ecobank.com/upload/201406190109107324279gS76quxnR.pdf (accessed December 23, 2015).

FAO, 2016. FAOstat, Food and Agriculture Organization, Rome, Italy. http://www.fao.org/faostat (accessed July, 2016).

Fold N., 2002. Lead firms and the competition in 'bi-polar' commodity chains: grinders and branders in the global cocoa-chocolate industry, J. Agrar. Change 2, 228-247.

Gayi S.K., Tsowou K., 2016. Cocoa industry: integrating small farmers into the global value chain (Document UNCTAD/SUC/2015/4), in: United Nations Conference on Trade and Development, United Nations, Geneva, Switzerland.

Gilbert C.L., 2009. Cocoa market liberalization in retrospect, Rev. Bus. Econ. 54, 294-313.

Goodwin B.K., 1994. Oligopsony power: a forgotten dimension of food marketing? discussion, Am. J. Agric. Econ. 76, $1163-1165$.

Griffith G., Piggott N., 1994. Asymmetry in beef, lamb and pork farm-retail price transmission in Australia, Agric. Econ. 10, $307-316$.

ICCO, 2006. Project on Pilot Plants to Process Cocoa By-Products, a Summary Report on a Pilot Project in Ghana (EX/131/7/Add.1). Document prepared by Dr. D.K. Adomako and the International Cocoa Organization (ICCO) secretariat, for the one hundred and thirty-first meeting of the Executive Committee, London, December 5-6. https://www.icco.org/about-us/international-cocoa-agreements/cat_view/50-projects.html.

ITC, 2001. Cocoa, A Guide to Trade Practices (Document ITC/P67.E/PMD/MDS/00-XII), International Trade Centre UNCTAD/WTO, Geneva, Switzerland. http://www.intracen.org/uploadedFiles/intracenorg/Content/Publications/Cocoa\%20-\%20A\%20Guide\%20to\%20Trade\%20Practices \%20English.pdf.

Johansen S., Juselius K., 1990. Maximum likelihood estimation and inference on cointegration — with applications to the demand for money, Oxf. Bull. Econ. Stat. 52, 169-210. 
Kamdem C.B., Galtier F., Gockowski J., Hélène D.B., Egg J., Dia B.K., 2010. What determines the price received by cocoa farmers in Cameroon? An empirical analysis based on bargaining theory, Afr. J. Agri. Resour. Econ. 6, 318-339.

Kaplinsky R., 2004. Competitions Policy and the Global Coffee and Cocoa Value Chains, UNCTAD, Geneva, Switzerland.

Kireyev A., 2010. Export tax and pricing power: two hypotheses on the cocoa market in Côte d'Ivoire, in: IMF Working Paper No. $10 / 269$. International Monetary Fund, Washington, DC. pp. 1-33.

Kolavalli S., Vigneri M., 2011. Cocoa in Ghana: shaping the success of an economy, in: Yes, Africa Can: Success Stories from a Dynamic Continent, World Bank, Washington, DC, pp. 201-217. http://siteresources.worldbank.org/AFRICAEXT/Resources/258643-1271798012256/Ghanacocoa.pdf.

Lambert A., 2014. The Fairness Gap: Farmer Incomes \& Solutions to Child Labor in Cocoa, International Labor Rights Forum, Washington, DC. Losch B., 2002. Global restructuring and liberalization: Côte d'Ivoire and the end of the international cocoa market?, J. Agrar. Change 2, $206-227$. Maccini L.J., 1978. The impact of demand and price expectations on the behavior of prices, Am. Econ. Rev. 68, 134-145.

Maddala G.S., Kim I.M., 1998. Unit Roots, Cointegration, and Structural Change (No. 4), Cambridge University Press.

Maurice N.E., Davis J., 2011. Unraveling the Underlying Causes of Price Volatility in World Coffee and Cacao Commodity Markets (Discussion paper 1), UNCTAD, Geneva, Switzerland. https://unctad.org/en/PublicationsLibrary/suc-miscDP01_en.pdf.

Meyer J., 2004. Measuring market integration in the presence of transaction costs-a threshold vector error correction approach, Agric. Econ. 31, $327-334$

Mundlak Y., Larson D.F., 1992. On the transmission of world agricultural prices, World Bank Econ. Rev. 6, $399-422$.

Neilson J., Fauziah K., Meekin A., 2013. Effects of an export tax on the farm-gate price of Indonesian cocoa beans, in: Paper presented at the Malaysian International Cocoa Conference, Kuala Lumpur, October 7-8.

Njoh A.J., 2008. Implications of Africa's transportation systems for development in the era of globalization, Rev. Black Polit. Econ. 35, $147-162$.

Panlibuton H., Lusby F., 2006. Indonesia Cocoa Bean Value Chain Case Study, Microreport 65, USAID, Washington, DC.

Quiroz J.A., Soto R., 1995. International Price Signals in Agricultural Markets: Do Governments Care?, Mimeo, GERENS and ILADES/Georgetown University. https://www.researchgate.net/publication/5115465_International_Price_Signals_in_Agricultural_Markets_DoGovernments_Care.

Rapsomanikis G., Hallam D., Conforti P., 2006. Market integration and price transmission in selected food and cash crop markets of developing countries: review and applications. In Agricultural commodity markets and trade: new approaches to analyzing market structure and instability, The Food and Agriculture Organization of the United Nations, Rome, Italy, pp. 187-217.

Scherer F.M., Ross D., 1990. Industrial market structure and economic performance, third ed., Houghton/Mifflin, Boston, MA.

Sharma R., 2003. The transmission of world price signals: concepts, issues and some evidence from Asian cereal markets, in: Paper submitted to the OECD Global Forum on Agriculture, OECD CCNM/GF/AGR(2002)10, pp. 141-159. https://www.econbiz.de/Record/agricultural-tradepoverty-making-policy-analysis-count-oecd-global-forum-agricultural-trade-reform-adjustment-poverty-held-paris-2002-brooksjonathan/10001733850.

Shepherd B., 2004. Market power in international commodity processing chains: preliminary results from the coffee market. Institute of Political Studies, Paris, France.

Ton G., Hagelaars G., Laven A., Vellema S., 2008. Chain governance, sector policies and economic sustainability in cocoa: a comparative analysis of Ghana, Côte d'Ivoire, and Ecuador, in: Markets, Chains and Sustainable Development Strategy and Policy paper, 12.

Traoré D., 2009. Cocoa and coffee value chains in West and Central Africa: constraints and options for revenue-raising diversification, in: FAOAAACP Paper Series, 3, The Food and Agriculture Organization of the United Nations, Rome, Italy.

UNCTAD, 2008. Cocoa Study: Industry Structures and Competition, in: United Nations Conference on Trade and Development, United Nations, Geneva, Switzerland. https://unctad.org/en/PublicationsLibrary/suc2015d4_en.pdf.

Vos R.P., 2000. Economic liberalization, adjustment, distribution and poverty in Ecuador, 1988-98, in: ISS Working Papers - General Series No. 19056, International Institute of Social Studies of Erasmus University Rotterdam (ISS), The Hague, The Netherlands. https://www.researchgate.net/publication/5130592_Economic_liberalization_adjustment_distribution_and_poverty_in_Ecuador_1988-98.

WCF, 2012. Cocoa Market Update [Internet]. World Cocoa Foundation. http://worldcocoafoundation.org/wp-content/uploads/Cocoa-MarketUpdate-as-of-3.20.2012.pdf (accessed March 11, 2015).

Wilcox M.D., Abbott P.C., 2004. Market power and structural adjustment: the case of West African cocoa market liberalization, in: Paper presented at the American Agricultural Economics Association Annual Meeting, Denver, CO, August 1-4. https://ideas.repec.org/p/ags/aaea04/20084.html.

Wilcox M.D., Abbott P.C., 2006. Can Cocoa Farmer Organizations Countervail Buyer Market Power?, in: 2006 Annual Meeting, July 23-26, Long Beach, CA (No. 21261), American Agricultural Economics Association. https://core.ac.uk/download/pdf/7055291.pdf.

Williams T., 2009. An African success story: Ghana’s cocoa marketing system, in: IDS Working Papers, pp. 1-47.

WTO, 2005. Trade Policy Review, Ecuador (Document WT/TPR/S/148/Rev.1), World Trade Organization, Geneva, Switzerland.

WTO, 2011. Trade Policy Review, Ecuador (Document WT/TPR/S/254), World Trade Organization, Geneva, Switzerland. https://www.wto.org/ english/tratop_e/tpr_e/tp354_e.html.

Worako T.K., van Schalkwyk H.D., Alemu Z.G., Ayele G., 2008. Producer price and price transmission in a deregulated Ethiopian coffee market, Agrekon 47, 492-508. 